DOI: $10.19195 / 2084-5065.48 .10$

\title{
Reguły Nelsona Mandeli
}

\author{
KAMILA MROZEK \\ ORCID: 0000-0001-7973-0281 \\ Zakład Prawa Karnego Wykonawczego \\ Wydział Prawa, Administracji i Ekonomii Uniwersytetu Wrocławskiego
}

Powołanie w latach 70. XIX wieku Międzynarodowej Komisji Penitencjarnej, przekształconej po I wojnie światowej w Międzynarodową Komisją Karną i Penitencjarną, rozpoczęło międzynarodowe zainteresowanie sytuacją osób pozbawionych wolności. Organizowane w tym czasie międzynarodowe kongresy penitencjarne pozwoliły na wypracowanie jednolitych zasad postępowania z osobami pozbawionymi wolności. Standardy te, przyjęte oficjalnie w 1934 roku przez Ligę Narodów, stworzyły zbiór określany mianem Reguł minimalnych postępowania z więźniami. Następnie, w latach 50. XX wieku międzynarodowymi zagadnieniami penitencjarnymi zajęła się Organizacja Narodów Zjednoczonych, która zastąpiła działającą aż do roku 1951 Międzynarodową Komisję Karną i Penitencjarną ${ }^{1}$. W roku 1955 w Genewie przyjęto Wzorcowe reguły minimalne postępowania $\mathrm{z}$ więźniami Wzorcowe reguły minimalne Organizacji Narodów Zjednoczonych dotyczące postępowania z więźniami, będące efektem prac Pierwszego Kongresu Narodów Zjednoczonych w sprawie zapobiegania przestępczości i postępowania ze sprawcami przestępstw. Dokument ten został ostatecznie przyjęty w formie rezolucji 663 CI z lipca 1957 roku przez Radę Gospodarczą i Społeczną ONZ. W celu wzmocnienia efektywnego wdrażania reguł Rada w roku

${ }^{1}$ E. Dawidziuk, Traktowanie osób pozbawionych wolności we współczesnej Polsce na tle standardów międzynarodowych, Warszawa 2013, s. 22. 
1976 zleciła Komitetowi do spraw Zapobiegania i Zwalczania Przestępczości opracowanie zbioru procedur służących upowszechnianiu sprawozdań z ich stosowania, który następnie dołączono do reguł w formie aneksu $^{2}$. Pierwotnie reguły obejmowały 94 zasady postępowania z osobami pozbawionymi wolności. W dniu 13 maja 1977 roku uzupełniono je o jedną dodatkową regułę określającą sytuację więźniów, którym nie przestawiono zarzutów ${ }^{3}$.

Idea znowelizowania dotychczas obowiązujących reguł minimalnych narodziła się w roku 2010. Dostrzeżono bowiem potrzebę uwzględnienia zmian politycznych, społecznych i gospodarczych, które w tym czasie zaszły na świecie. W rezolucji z dnia 21 grudnia 2010 roku, zatytułowanej Dwunasty Kongres Organizacji Narodów Zjednoczonych w sprawie zapobiegania przestępczości i wymiaru sprawiedliwości sadownictwa karnego, Zgromadzenie Ogólne zaleciło Komisji ds. Zapobiegania Przestępczości i Wymiaru Sprawiedliwości Sądownictwa Karnego stworzenie otwartej międzynarodowej Grupy Eksperckiej w celu podjęcia działań w kierunku nowelizacji istniejących Wzorcowych reguł minimalnych Narodów Zjednoczonych, dotyczących postępowania z więźniami, a także wymiany informacji na temat najlepszych praktyk, jak również przepisów krajowych i istniejącego prawa międzynarodowego. Zintensyfikowane prace, obejmujące liczne konsultacje techniczne i eksperckie, prowadzone były w latach 2010-2015. W tymże czasie odbyły się również trzy posiedzenia Grupy Eksperckiej, kolejno: w Buenos Aires w dniach od 11 do 13 grudnia 2012 roku, w Wiedniu w dniach od 25 do 28 marca 2014 roku oraz w Cape Town, w RPA, w dniach od 2 do 5 marca 2015 roku.

Zakres nowelizacji koncentrował się wokół dziewięciu obszarów tematycznych dotyczących kolejno:

- poszanowania przyrodzonej godności więźniów i ich wartości jako istot ludzkich;

— usług medycznych;

2 A. Kwieciński, Wykonywanie kary pozbawienia wolności w systemie terapeutycznym, Warszawa 2017, s. 78-79.

3 G. Michałowska, Ochrona praw człowieka $w$ Radzie Europy $i$ w Unii Europejskiej, Warszawa 2007, s. 80. 
— dyscypliny i kar, w tym roli personelu medycznego, odosobnienia i ograniczenia racji żywnościowej;

— badania wszystkich przypadków zgonów w areszcie, jak również jakichkolwiek oznak lub zarzutów stosowania tortur lub nieludzkiego lub poniżającego traktowania albo karania więźniów;

- ochrony i specjalnych potrzeb podatnych grup osób pozbawionych wolności, z uwzględnieniem krajów znajdujących się w trudnych warunkach;

- prawa dostępu do obrońcy;

— skarg i niezależnych inspekcji;

— zmiany przestarzałej terminologii;

— szkolenia personelu w celu wdrożenia Wzorcowych reguł minimalnych.

Jednocześnie wyraźnie podkreślano, że wszelkie zmiany we Wzorcowych regułach minimalnych nie powinny mieć mniejszego zakresu niż jakiekolwiek istniejące standardy, lecz mają odzwierciedlać najnowsze postępy w zakresie nauk penitencjarnych i dobrych praktyk, tak aby promować bezpieczeństwo i humanitarne warunki dla więźniów.

W dniu 12 kwietnia 2015 roku, w Ad-Dausze (Katar), rozpoczął się — trwający tydzień - Trzynasty Kongres Organizacji Narodów Zjednoczonych w sprawie zapobiegania przestępczości i wymiaru sprawiedliwości sądownictwa karnego, podczas którego pozytywnie zaaprobowano projekt znowelizowanych Wzorcowych reguł minimalnych postępowania z więźniami. Reguły Mandeli ${ }^{4}$ zostały ostatecznie przyjęte w październiku 2015 roku w Nowym Jorku.

Ograniczone ramy publikacji zadecydowały o wyborze ścisłego zakresu tematycznego, skupiającego się wyłącznie na analizie zmian Wzorcowych reguł minimalnych, uwzględnionych w Regułach Mandeli.

Dokument ten zawiera 122 reguły zapisane w dwóch odrębnych częściach. Całość poprzedza preambuła, która stanowi: „resocjalizacja i reintegracja osób pozbawionych wolności są jednymi z najważniejszych celów systemu wymiaru sprawiedliwości w sprawach karnych, na ile jest to możliwe zapewniając, że przestępcy są w stanie prowadzić prawo-

${ }^{4}$ Na cześć spuścizny prezydenta RPA, Nelsona Rolihlahla Mandeli, który spędził w więzieniu 27 lat podczas swojej walki o globalne prawa człowieka, równość, demokrację i promocję kultury pokoju. 
rządne i niezależne życie po swoim powrocie do społeczeństwa"5. Powołując się nadto na rezolucję 69/172 z dnia 18 grudnia 2014 roku pod tytułem Prawa człowieka w wymiarze sprawiedliwości, przypomina, ,iż — z wyjątkiem tych zgodnych z prawem ograniczeń, które w oczywisty sposób wynikają z faktu pozbawienia wolności — osoby pozbawione wolności zachowują swoje bezwzględnie obowiązujące prawa człowieka oraz wszystkie inne prawa człowieka i podstawowe swobody" 6 .

Część pierwsza, zatytułowana „Zasady o zastosowaniu ogólnym”, zawiera ogólne regulacje odnoszące się do wszystkich kategorii skazanych, tj. więźniów kryminalnych, osób pozbawionych wolności z tytułu odpowiedzialności cywilnej, osób nieosądzonych bądź skazanych, włącznie z więźniami poddanymi ,środkom bezpieczeństwa” lub środkom poprawczym orzeczonym przez sędziego. „Reguły stosowane do poszczególnych kategorii więźniów”, zawarte w części drugiej, odnoszą się natomiast kolejno do: skazanych, więźniów chorych psychicznie i lub upośledzonych umysłowo, osób zatrzymanych oraz aresztowanych, przy czym wśród ostatniej kategorii wyróżnia się osoby pozbawione wolności z tytułu odpowiedzialności cywilnoprawnej (reguła 121) oraz osoby zatrzymane lub aresztowane bez przedstawiania zarzutów (reguła 122). W uwagach wstępnych (3) wyjaśniono jednak, iż reguły przewidziane w rozdziale A, odnoszące się do więźniów skazanych, znajdują odpowiednie zastosowanie do pozostałych kategorii więźniów, o których mowa w części drugiej, pod warunkiem że nie będą one sprzeczne z regułami odnoszącymi się do poszczególnych grup i będą dla nich korzystne. Ta część Reguł Mandeli pomija jednak regulacje skupiające się wokół wykonywania kary pozbawienia wolności wobec szczególnej kategorii skazanych, jaką tworzą młodociani przestępcy. Niemniej w uwagach wstępnych (4) wyjaśniono, iż zasadniczo regulacje zawarte w części pierwszej Reguł winny znaleźć zastosowanie także i w tym przypadku.

Część pierwsza Reguł Mandeli redakcyjnie dzieli się na 21 rozdziałów koncertujących się wokół problematyki wykonywania kary pozbawie-

5 Wzorcowe reguly minimalne Organizacji Narodów Zjednoczonych dotyczace postępowania z więźniami (Reguly Mandeli), preambuła, s. 4, https://www.rpo.gov.pl/ sites/default/files/Reguly_Mandeli.pdf (dostęp: 21.09.2018).

${ }^{6}$ Ibidem. 
nia wolności. Poruszane są zagadnienia dotyczące: zasad podstawowych (reguły od 1 do 5, ewidencji (reguły 6-10), oddzielenia poszczególnych kategorii więźniów (reguła 11), zakwaterowania (reguły 12-17), higieny osobistej (reguła 18), odzieży i pościeli (reguły 19-21), żywności (reguła 22), ćwiczeń fizycznych i sportu (reguła 23), usług medycznych (reguły 24-35), ograniczeń, dyscypliny i kar (reguły 36-46), środków przymusu (reguła 47-49), przeszukania więźniów i cel (reguły 50-53), informowania więźniów i skarg więźniów (reguły 54-57), kontaktu ze światem zewnętrznym (reguły 58-63), książek (reguły 64-66), przechowywania przedmiotów stanowiących własność więźniów (reguła 67), powiadamiania (reguły 68-70), dochodzeń (reguły 71-72), przenoszenia więźniów (reguła 73), personelu instytucji o charakterze izolacyjnym (reguły 74-82) oraz dotyczące inspekcji wewnętrznych i zewnętrznych (reguły 83-85).

Krótkiego wyjaśnienia wymaga również kwestia oceny statusu prawnego Reguł Mandeli. Jak wynika bowiem z ust. 8 uwag wstępnych, Reguły te nie mają mocy prawnie wiążącej dla państw, do których są adresowane. $\mathrm{Z}$ prawnomiędzynarodowego punktu widzenia reprezentują one tak zwane soft-law, a więc prawo nierodzące formalnych obligacji prawnych dla poszczególnych państw, lecz prawo tworzące jedynie powinności w sferze moralno-politycznej, bez konieczności wdrażania tradycyjnych procedur międzynarodowych ${ }^{7}$. Oznacza to, że dokument ten pozbawiony jakichkolwiek bezpośrednich mechanizmów implementacyjno-kontrolnych nie ma charakteru wiążącego dla Polski, lecz powinien być brany pod uwagę przy stanowieniu prawa krajowego. Co istotne, z uwagi na różnorodność struktur prawnych państw członkowskich, a także różnorodność uwarunkowań społecznych, gospodarczych i geograficznych, stosowanie Reguł w całości w sposób jednolity w poszczególnych systemach krajowych jest niemalże niemożliwe. Dlatego też autorzy Reguł podkreślają, iż „powinny stymulować podejmowanie stałych wysiłków mających na celu przezwyciężenie praktycznych trudności

7 D. Gajdus, B. Gronowska, O potrzebie działań na rzecz poprawy sytuacji więźniów. Uwagi na tle standardów międzynarodowych, ,Toruński Rocznik Praw Człowieka i Pokoju" 1996, z. 4, s. 71. 
w ich realizacji, ze świadomością, że jako całość reprezentują one minimalne warunki uznane przez Narody Zjednoczone za odpowiednie"

Jak wspomniano na wstępie niniejszej pracy, zakres nowelizacji Wzorcowych reguł minimalnych koncentruje się wokół dziewięciu starannie wyselekcjonowanych obszarów tematycznych. Zmiany dostrzega się już w ramach rozdziału pierwszego regulującego zagadnienie dotyczące poszanowania przyrodzonej godności więźniów i ich wartości jako istot ludzkich. Reguły Mandeli wyraźnie akcentują zasadę zakazującą stosowania tortur oraz innego okrutnego, nieludzkiego lub poniżającego traktowania albo karania. Przypominają jednocześnie o obowiązku traktowania osób pozbawionych wolności z szacunkiem wynikającym z ich przyrodzonej godności i wartości jako istot ludzkich oraz obowiązku respektowania zasady niedyskryminacji. Reguła 3 zakazuje - w toku wykonywania kary izolacyjnej — kreowania dodatkowej, większej dolegliwości niż wynikającej z samego faktu pozbawienia wolności. Zasada ta nie obejmuje jednak sytuacji wynikających z uzasadnionego odseparowania lub zastosowania odpowiednich środków w celu utrzymania dyscypliny.

Reguły definiują również cele wykonywania kary pozbawienia wolności, wskazując przede wszystkim na potrzebę ochrony społeczeństwa przed przestępczością (prewencja ogólna) oraz zmniejszenia liczby przypadków recydywy (prewencja szczególna). Osiągnięcie założonego celu możliwe jest dzięki stosowaniu zindywidualizowanych metod i środków oddziaływania penitencjarnego, o których mowa w ust. 2 reguły 4 Kodeksu Reguł Mandeli.

Nowelizacji poddano również kwestię dotyczącą ewidencji skazanych. Zmiana ta nie ma jednak charakteru rewolucyjnego, a związana jest wyłącznie z rozwojem nowych technologii. Wprowadzono bowiem możliwość korzystania z elektronicznej bazy danych, pozostawiając w dalszym ciągu możliwość prowadzenia ksiąg ewidencyjnych. Istotnie rozszerzono zakres danych osobowych umieszczanych w systemie ewidencji, podkreślając obowiązek zapewnienia poufności oraz pełnej ich ochrony.

8 Wzorcowe reguty minimalne Narodów Zjednoczonych dotyczace postępowania $z$ więźniami (Reguty Mandeli), Aneks, Uwaga wstępna 2, pkt 1, s. 8, https://www.rpo.gov. pl/sites/default/files/Reguly_Mandeli.pdf, (dostęp: 21.09.2018). 
Najszerzej zmodyfikowano rozdział poświęcony usługom medycznym. W regule 24 wprowadzono obowiązek zapewnienia skazanym dostępu do opieki zdrowotnej na takim samym poziomie, jaki dostępny jest na wolności, podkreślając równocześnie, że zadanie to wpisuje się w treść obowiązków każdego państwa. Usługi te powinny być świadczone bezpłatnie, bez jakiejkolwiek dyskryminacji ze względu na status osób uwięzionych. Reguły Mandeli zwracają nadto uwagę na fakt, iż organizacja usług medycznych w zakładach karnych powinna być powiązana $\mathrm{z}$ powszechną służbą zdrowia, zwłaszcza $\mathrm{w}$ odniesieniu do leczenia HIV, gruźlicy lub innych chorób zakaźnych oraz uzależnienia. Reguła 25 nakłada na administrację penitencjarną obowiązek zatrudnienia personelu zajmującego się oceną, promowaniem, ochroną i poprawą fizycznego i psychicznego zdrowia więźniów. Szczególną uwagę zwrócić należy na sytuację osób ze specjalnymi potrzebami medycznymi lub problemami zdrowotnymi hamującymi proces ich rehabilitacji. Kolejne dwie reguły rozstrzygają kwestie dotyczące gromadzenia, zabezpieczania oraz dostępu do dokumentacji medycznej skazanych oraz dostępu do opieki lekarskiej w nagłych przypadkach. Zastrzeżono, że decyzje lekarskie mogą podejmować wyłącznie pracownicy służby zdrowia. Uregulowano także sytuację kobiet i dzieci w warunkach izolacji penitencjarnej, nakładając na administrację obowiązek zapewnienia wewnętrznych lub zewnętrznych żłobków z wykwalifikowanym personelem oraz zapewniając świadczenie w takiej placówce pediatrycznych usług medycznych. Po raz kolejny zwrócono uwagę na kwestię dotyczącą zakazu stosowania tortur lub innego okrutnego, nieludzkiego lub poniżającego traktowania albo karania, nakładając na pracowników służby zdrowia obowiązek zgłoszenia takiego faktu właściwemu organowi medycznemu, administracyjnemu lub sądowemu (reguła 30, 32 i 34). W regule 32 jasno określono również charakter relacji, jaka powinna łączyć lekarza lub innego wykwalifikowanego pracownika służby zdrowia ze skazanym, nakazując stosowanie analogicznych zasad do tych, jakie łączą te podmioty z pacjentami znajdującymi się na wolności.

Zmiany obejmują również fragment dotyczący ograniczeń, dyscypliny i kar stosowanych wobec osób pozbawionych wolności. W tym kontekście na szczególną uwagę zasługuje treść reguły 38, która zachęca do korzystania z wszelkich dostępnych narzędzi służących zapobieganiu 
konfliktom, promując mediację oraz inne alternatywne metody rozwiązywania sporów.

Reguły Mandeli podkreślają znaczenie zasady proporcjonalności sankcji karnych do stopnia przekroczenia dyscyplinarnego, którego kara dotyczy, zalecając jednocześnie prowadzenie specjalnych rejestrów wszystkich sankcji nałożonych w toku wykonywania kary. Każdorazowo przed wymierzeniem sankcji dyscyplinarnej należy zbadać przyczynę negatywnego zachowania skazanego w jednostce penitencjarnej, zwracając szczególną uwagę na jego stan zdrowia, zwłaszcza w kontekście występowania choroby psychicznej lub upośledzenia umysłowego. Okoliczności te powinny bezwzględnie wyłączać możliwość nałożenia na skazanego jakiejkolwiek kary dyscyplinarnej. Reguła 42 wprowadza nakaz respektowania podstawowych praw skazanych $\mathrm{w}$ toku postępowania dyscyplinarnego, obejmujących: obowiązek poinformowania o treści stawianego zarzutu, prawo do obrony formalnej i materialnej, prawo do korzystania z pomocy tłumacza, prawo zaskarżenia niekorzystnego rozstrzygnięcia oraz prawo do rzetelnego procesu w sytuacji, gdy przekroczenie stanowi przestępstwo spenalizowane w ustawie karnej i podlegające jurysdykcji sądów powszechnych. Zbiór wprowadza również bezwzględny zakaz stosowania tortur lub innego nieludzkiego lub poniżającego traktowania lub karania, w szczególności stosowania kar w postaci: bezterminowego oraz przedłużonego odosobnienia ${ }^{9}$, umieszczenia skazanego w ciemnej lub stale oświetlonej celi, kar cielesnych, ograniczenia racji żywnościowej lub ilości spożywanej wody oraz stosowania kar zbiorowych. Zakazuje nadto krępowania skazanych oraz całkowitego pozbawienia możliwości utrzymywania kontaktów z rodziną oraz światem zewnętrznym. W hierarchii poszczególnych kar dyscyplinarnych najwięcej uwagi Reguły poświęcają odosobnieniu skazanych. $Z$ jednej strony zalecają ograniczenie stosowania tej sankcji tylko do wyjątkowych przypadków, przy uwzględnieniu maksymalnie krótkiego czasu jej trwania. Z drugiej zaś wykluczają z kręgu potencjalnych odbiorców skazanych upośledzonych psychicznie lub fizycznie w sytuacji, gdy mogłoby to negatywnie wpły-

9 Reguła 44 definiuje pojęcie „odosobnienia”, przyjmując, że kara ta odnosi się do umieszczenia więźnia w osobnej celi na 22 lub więcej godzin dziennie, bez znaczącego kontaktu z drugą osobą. Przedłużające się odosobnienie oznacza natomiast umieszczenia więźnia w oddzielnej celi na okres powyżej 15 kolejnych dni. 
nąć na pogorszenie ich stanu zdrowia, także skazane kobiety oraz dzieci. Wreszcie, określają rolę personelu medycznego w procesie wykonywania kar dyscyplinarnych, koncentrując ją wokół obowiązku zapewnienia skazanym bezpiecznych warunków ich realizacji.

Reguły wprowadzają nadto niewielkie zmiany w obrębie rozdziału poświęconego środkom przymusu. Sprecyzowano bowiem ogólne zasady ich stosowania, podkreślając znaczenie zasady ultima ratio, zasady nieinwazyjności oraz ograniczonego czasu ich stosowania. Wprowadzono wyraźny zakaz stosowania środków przymusu wobec kobiet w ciąży, podczas porodu i zaraz po porodzie.

Reguły Mandeli regulują zasady dokonywania przeszukań więźniów i cel (reguła 50-53). Warto zaznaczyć, że Wzorcowe reguły minimalne postępowania z więźniami, przyjęte w Genewie w roku 1955, pomijały tę kwestię. Kodeks akcentuje W Regułach akcentuje się cztery podstawowe zasady gwarantujące ochronę praw osób przeszukiwanych: zasadę poszanowania przyrodzonej godności ludzkiej i prywatności osoby przeszukiwanej, zasadę proporcjonalności, legalności i konieczności. Jednocześnie wprowadza zakaz wykorzystywania przeszukań w celu nękania, zastraszania czy niepotrzebnego naruszania prywatności skazanych. Zasady te doznają jednak pewnego ograniczenia $\mathrm{z}$ uwagi na obowiązek - przy ich poszanowaniu - zapewnienia przez administrację bezpieczeństwa w zakładzie karnym. Autorzy Reguł zwracają nadto uwagę na konieczność zapewnienia spójności przepisów krajowych regulujących przeszukania więźniów i cel z prawem międzynarodowym.

W celu stworzenia narzędzi kontrolnych nad prawidłowością prowadzenia przeszukań wprowadzono obowiązek rejestracji wszelkich czynności z tym związanych w zakresie: przeszukań osobistych i szczegółowych oględzin ciała, przeszukań cel, przyczyn oraz wyników przeszukań, a także tożsamości osób biorących w nich udział. Jednocześnie zwrócono uwagę na ultima ratio przeszukań inwazyjnych, a zwłaszcza rewizji osobistych i szczegółowych oględzin ciała, zalecając poszukiwanie rozwiązań alternatywnych. Standardem powinno być dokonywanie przeszukań w sposób dyskretny, tylko i wyłącznie przez osoby przeszkolone, tej samej płci, co skazany. Szczegółowe oględziny ciała powinny być przeprowadzane przez wykwalifikowanych pracowników służby zdrowia, ewentualnie przez personel odpowiednio przeszkolony przez 
pracownika medycznego w zakresie standardów higieny i BHP. Regulacje dotyczące standardów w zakresie przeszukania cel koncentrują się wokół prawa skazanych do możliwości posiadania w celi lub dostępu do dokumentów związanych z toczącym się postępowaniem sądowym względem nich, bez możliwości wglądu w te dokumenty przez personel administracji penitencjarnej (reguła 53).

W obrębie rozdziału zatytułowanego „Informowanie więźniów i skargi więźniów" (reguła 54-57) zagwarantowano skazanym możliwość realizowania szeroko rozumianego prawa do składania wniosków lub skarg także za pomocą ustanowionego obrońcy, członka rodziny lub jakiejkolwiek innej osoby dysponującej wiedzą w sprawie. Co istotne, Reguły Mandeli wprowadzają obowiązek sądowej lub pozasądowej kontroli zasadności odrzucania wniosków lub skarg oraz respektowania zasady rozpoznawania ich bez nieuzasadnionej zwłoki. Podkreślają nadto szczególną wagę skarg dotyczących stosowania tortur lub innego okrutnego, nieludzkiego lub poniżającego traktowania albo karania, wprowadzając obowiązek natychmiastowego ich rozpoznania, po przeprowadzeniu szybkiego i bezstronnego dochodzenia. W zakresie obowiązku informowania skazanych o podstawowych prawach i obowiązkach oraz wymogach dyscyplinarnych, a także o treści przepisów szczególnych dotyczących postępowania $\mathrm{z}$ wybraną grupą osadzonych, do których skazany należy, uwzględniono barierę językową, zapewniając obowiązek doręczenia treści informacji w jednym $\mathrm{z}$ najpowszechniej stosowanych języków bądź z tłumaczeniem na język zrozumiały dla skazanego oraz potrzeby skazanych z niepełnosprawnością sensoryczną.

Nieznacznie zmodyfikowano fragment poświęcony kontaktom skazanych ze światem zewnętrznym. Po pierwsze, zarekomendowano umieszczanie skazanych $w$ jednostkach penitencjarnych położonych najbliżej miejsca zamieszkania lub resocjalizacji. Po drugie, uregulowano zasady kontaktowania się osadzonego z obrońcą bądź inną osobą świadczącą pomoc prawną, zapewniając poufność takich kontaktów oraz zakazując stosowania podsłuchów oraz cenzury, przy poszanowaniu zasady realizacji kontaktów bez zbędnej zwłoki. Po trzecie wreszcie, ustalono zasady dokonywania przeszukań osób odwiedzających, zapewniając im co najmniej taką ochronę, jaką reguly gwarantują osobom odbywającym karę pozbawienia wolności. 
Reguła 71 i 72 ustala zasady prowadzenia tak zwanych zewnętrznych dochodzeń, tj. dochodzeń prowadzonych przez organy sądowe lub inne właściwe organy działające niezależnie od administracji penitencjarnej w przypadku śmierci, zaginięcia lub poważnego urazu osadzonego. Zasady te obejmują w takim samym zakresie przypadki, w których istnieje podejrzenie stosowania tortur lub innego okrutnego, nieludzkiego lub poniżającego traktowania lub karania. Warto wspomnieć, iż Wzorcowe reguły minimalne z 1955 roku nie normowały tego zagadnienia. Kodeks ten Reguły Mandeli normuje nadto zasady postępowania administracji więziennej w razie stwierdzenia zgonu w jednostce penitencjarnej.

W kolejnym rozdziale („Personel instytucji o charakterze izolacyjnym") skonkretyzowano obszar obowiązkowych szkoleń pracowników służby więziennej, wskazując na minimum obejmujące znajomość: przepisów krajowych i polityk oraz właściwych międzynarodowych i regionalnych instrumentów określających zasady pracy i interakcji personelu zakładu karnego z więźniami, praw i obowiązków personelu zakładu w wykonywaniu swoich funkcji, w tym respektowania godności ludzkiej wszystkich więźniów oraz całkowitego zakazu pewnych zachowań, w szczególności tortur oraz innego okrutnego, nieludzkiego lub poniżającego traktowania albo karania, zasad bezpieczeństwa, w tym koncepcji bezpieczeństwa dynamicznego, wykorzystania siły i środków przymusu, a także zarządzania przestępcami agresywnymi, z należytym uwzględnieniem działań zapobiegawczych i technik rozładowania napięcia, takich jak negocjacje i mediacja, oraz zasad udzielania pierwszej pomocy, potrzeb psychosocjalnych więźniów oraz właściwej dynamiki więziennej, a także opieki i pomocy społecznej, w tym wczesnego wykrywania problemów związanych ze zdrowiem psychicznym.

Reguły Mandeli istotnie nowelizują materię dotyczącą inspekcji zakładów karnych i służb penitencjarnych, wprowadzając tak zwany system podwójnych inspekcji: wewnętrznych (przeprowadzanych przez administrację więzienną) i zewnętrznych (przeprowadzanych przez organ niezależny od administracji więziennej). Reguła 84 jasno formułuje zakres kompetencji tych inspektorów, zapewniając im między innymi prawo dostępu do wszelkich informacji o liczbie więźniów oraz miejscach ich zatrzymania, prawo do swobodnego wyboru wizytowanych zakładów karnych czy prawo do prowadzenia rozmów z osobami pozba- 
wionymi wolności oraz personelem bez obecności innych osób. Z każdej przeprowadzonej inspekcji zaleca się sporządzenie pisemnego raportu, który zostanie następnie upubliczniony w sposób zapewniający ochronę danych osobowych.

Część druga Reguł, podzielona redakcyjnie na cztery części (skazani, więźniowie chorzy psychicznie i/lub upośledzeni umysłowo, osoby zatrzymane lub aresztowane oraz osoby pozbawione wolności z tytułu odpowiedzialności cywilnoprawnej, a także osoby zatrzymane lub aresztowane bez przedstawiania zarzutów), które znajdują zastosowanie tylko do poszczególnych kategorii osób pozbawionych wolności, w zasadzie nie zawiera większych zmian w porównaniu z Wzorcowymi regułami minimalnymi.

Reguły Mandeli stanowią, iż ,wszyscy więźniowie odbywający wyrok będą mieć możliwość podjęcia pracy i/lub aktywnego uczestniczenia w swojej rehabilitacji, odpowiednio do ich zdolności fizycznych i psychicznych stwierdzonych przez lekarza lub innego wykwalifikowanego pracownika służby zdrowia" (reguła 96)"10. Reguły minimalne natomiast mówią, iż od wszystkich więźniów odbywających wyrok będzie się wymagać pracy, odpowiednio do ich zdolności fizycznych i psychicznych stwierdzonych przez lekarza. Obecnie zatem umożliwiono skazanym podjęcie pracy, wprowadzając równocześnie zakaz pracy niewolniczej oraz poddańczej, a także jej wykonywania na korzyść własną lub prywatną jakiegokolwiek pracownika zakładu karnego.

W obrębie części B (więźniowie chorzy psychicznie i/lub upośledzeni umysłowo) w regule 109 wprowadza się, oprócz osób uznanych za chore psychicznie, odrębną kategorię osadzonych, mianowicie osoby, które nie ponoszą odpowiedzialności karnej bądź u których zdiagnozowano upośledzenie umysłowe - nakazując umieszczenie ich w placówkach zdrowia psychicznego w sytuacji, gdy przebywanie w zakładzie karnym wiązałoby się dla nich z zaostrzeniem stanu zdrowia. Ostatnia już zmiana koncentruje się wokół problematyki osób zatrzymanych oraz aresztowanych, a dokładnie wokół prawa do obrony. Reguły Mandeli w przypadku zatrzymania lub tymczasowego aresztowania zapewniają prawo do korzystania z pomocy obrońcy, w tym do korzystania z po-

10 Wzorcowe reguty..., s. 32. 
mocy obrońcy z urzędu we wszystkich przypadkach, gdy wymaga tego interes wymiaru sprawiedliwości oraz gdy zatrzymany lub tymczasowo aresztowany nie posiada wystarczających środków finansowych do korzystania z tego prawa. Gwarantują obowiązek poinformowania osób nieosądzonych o przyczynach zatrzymania oraz o stawianych zarzutach. Wprowadzają nadto kontrolę wszystkich sytuacji, w których odmówiono tej kategorii osadzonym dostępu do usług obrońcy.

Ochrona praw osób pozbawionych wolności od wielu lat jest przedmiotem szczególnego zainteresowania na arenie międzynarodowej. Efektem tego zainteresowania są liczne akty prawa międzynarodowego, których wspólnym mianownikiem jest poprawa sytuacji osób pozbawionych wolności. Co warte podkreślenia, w sferze standardów penitencjarnych współczesne organizacje zajmujące się ochroną praw człowieka zaoferowały najwięcej w płaszczyźnie tak zwanego soft law ${ }^{11}$. Na szczeblu zarówno uniwersalnym (ONZ), jak i regionalnym (Rada Europy) udało się wypracować jednolite standardy postępowania z osobami pozbawionymi wolności, których fundamentem jest zasada poszanowania ich godności oraz humanitarnego traktowania, a także nakaz przestrzegania bezwzględnie obowiązującego zakazu tortur oraz innego okrutnego, nieludzkiego lub poniżającego traktowania albo karania. Mimo iż Reguły Mandeli są standardem normatywnym niemającym mocy prawnie wiążącej, państwa członkowskie ONZ powinny uwzględniać ich treść przy kształtowaniu prawa wewnętrznego i podejmować wysiłki zmierzające do ich faktycznej realizacji — ich stosowanie w praktyce penitencjarnej odgrywa znaczącą rolę w przestrzeganiu niezbędnego minimum praw osób odbywających karę pozbawienia wolności. Głównym celem Reguł Mandeli jest bowiem promowanie penitencjarnego modelu oddziaływania na skazanych, opartego o ideę progresji i społecznej rehabilitacji tych osób. Akt ten ma być również gwarantem podmiotowego traktowania osadzonych, odpowiedniego doboru kadry penitencjarnej, odpowiedniej klasyfikacji osadzonych oraz zapewnienia skazanemu prawa do kontaktu ze światem zewnętrznym.

Mimo powszechności stosowania Reguł Mandeli w polskiej rzeczywistości penitencjarnej należy pamiętać, iż nieprzerwanie wymagają one

11 D. Gajdus, B. Gronowska, Europejskie standardy traktowania więźniów, Toruń 1998, s. 26. 
popularyzacji nie tylko w kręgu funkcjonariuszy Służby Więziennej, lecz również w kręgu wszelkich innych podmiotów zajmujących się wykonywaniem kary pozbawienia wolności oraz pozostałych środków o charakterze izolacyjnym. Znaczenie międzynarodowego dorobku normatywnego typu soft-law zależy przede wszystkim od zaangażowania w jego materializację osób, które na co dzień uczestniczą w wykonywaniu kar oraz środków o charakterze izolacyjnym.

\section{Nelson Mandela Rules}

\section{Summary}

The publication is entirely devoted to the UN Standard Minimum Rules for the Treatment of Prisoners from 2015. However, due to their large size, this work focuses solely on the comparison of the presently valid rules with those from the UN Standard Minimum Rules for the Treatment of Prisoners from 2015 accepted in Geneva in 1955. The changes have been discussed one by one. The work also explains the evaluation of the legal status of the UN Nelson Mandela Rules because as a recommendation they lack the binding legal provisions. Nevertheless, they should become not only the generally accepted standard of prisoner protection against maltreatment, but even more so the model of penitentiary influence on convicts.

Keywords: The Mandela Rules, convict, medical services, prison sentence, international law. 